\title{
Breastfeeding and the incidence of endometrial cancer: A meta-analysis
}

\author{
Baojian Zhan ${ }^{1}$, Xiaoqin Liu' ${ }^{1}$, Fang $\mathrm{Li}^{1}$, Dongfeng Zhang ${ }^{1}$ \\ ${ }^{1}$ Department of Epidemiology and Health Statistics, the Medical College of Qingdao University, Qingdao, Shandong Province, \\ People's Republic of China \\ Correspondence to: \\ Dongfeng Zhang, e-mail: zhangdf1961@126.com, zhangdf1962@aliyun.com \\ Keywords: endometrial cancer, breastfeeding, meta-analysis, dose-response \\ Received: May 22, $2015 \quad$ Accepted: August 24, $2015 \quad$ Published: September 05, 2015
}

\section{ABSTRACT}

Several epidemiological studies have investigated the association between breastfeeding and endometrial cancer (EC). However, the results of the studies are controversial. Thus, we conduct this meta-analysis to explore the association between breastfeeding and EC and to evaluate the possible does-response relationship between duration of breastfeeding and EC. PubMed, Web of Science, Chinese National Knowledge Infrastructure, China biology medical literature database, Wan fang databases and Database of Chinese Scientific and Technical Periodicals were searched for eligible observational studies up to 11 July 2015. Random effects model was used to calculate the pooled relative risks (RRs) and restricted cubic spline model was adopted for the does-response analysis.

Fifteen articles with 623570 participants were identified. The RRs of these studies suggested that breastfeeding was associated with the reduced risk of EC (high versus low/no: $R R=0.74 ; 95 \%$ confidence interval $(C I), 0.58-0.95)$.In subgroup analyses, a significant association of breastfeeding with EC risk was found in Asia $(R R=0.57,95 \%$ CI 0.37-0.87), and an inverse association of breastfeeding with EC risk was found in cohort studies $(R R=0.62,95 \% C I$ 0.41-0.94). The results were also significant after adjusted for hormone use $(R R=0.63,95 \% C I 0.41-0.97)$ and body mass index $(R R=0.65,95 \% C I$ 0.44-0.96). A linear relationship was found of breastfeeding with EC ( $p$ for nonlinearity $=0.93$ ), and it indicated that EC risk decreased by $1.2 \%$ for one month increment of breastfeeding. This meta-analysis indicates that long term breastfeeding might be associated with decreased risk of EC.

\section{INTRODUCTION}

Endometrial cancer (EC) is one of the most common malignancies among women. There were 320,000 new cases diagnosed in 2012 worldwide $[1,2]$, and the numbers of new EC cases and deaths were on the increase $[1,3,4]$. Present studies indicate that genetic factors, anthropometric factors and life style factors may be related to EC risk [5-7]. EC is thought to be caused by the continuous stimulation of estrogen [8], so conditions related to estrogen may alter EC risk, such as menstrual history, parity and exogenous hormones [9-11].

Breastfeeding is an essential biological function of humans and the beneficial effects of breastfeeding for both mother and child are widely acknowledged [12-14]. Meta-analyses found that breastfeeding was associated with breast cancer, ovarian cancer and childhood leukemia [15-17]. Breastfeeding may influence the risk of EC, because of the hormonal changes during breastfeeding.

Several epidemiological studies have investigated the association between breastfeeding and EC [18-22]. However, the results of the studies are inconsistent. Some studies suggest that breastfeeding can reduce the risk of endometrial cancer [21-23], while Herrinton LJ, and Dossus, L found no association between breastfeeding and EC [19, 24]. We conduct this meta-analysis to explore the association between breastfeeding and EC and to evaluate the possible doesresponse relationship of duration of breastfeeding with EC. 


\section{RESULTS}

\section{Literature search and study characteristics}

We identified 9109 articles by the search strategy and 3 articles by searching reference lists, of which 9000 articles were excluded after review of the title/abstract or which were duplicated (Figure 1). One hundred and twelve full-text articles were reviewed. We further excluded 97 articles that did not provide $R R$ s concerning the relation between breastfeeding and EC. Eventually 15 published articles [18-32] with 623570 participants were included in this analysis, of which 8 studies [19, 21-23, 25-27, 30] provided different duration of breastfeeding for the does-response relationship. The detailed characteristics of the 15 studies are shown in Table 1 .

Among the 15 studies, five studies [18, 20, 24, $26,30]$ were conducted in North America, five studies $[23,27,28,30,31]$ were conducted in Asia, and four studies $[19,25,29,32]$ were conducted in Europe. Regarding to the study type, 12 studies $[18,20-26$, 29-32] were case-control (CC) designs and three [19, 27, 28] were cohort studies. The Newcastle-Ottawa score of quality assessment showed that the scores of 13 studies were more than 7 , indicating that the methodological quality was generally good (Supplementary Table S1).

\section{Quantitative synthesis}

\section{Overall association between breastfeeding and EC risk}

The pooled $R R$ of overall data by the random effects model (REM) was 0.74 (95\% CI 0.58-0.95). We have separated the results by ever breastfeeding and the duration of breastfeeding. The pooled $R R$ of 14 studies [18-24, 26-32] was 0.88 (95\% CI 0.72-1.06) for the ever breastfeeding compared with the reference group. The association between breastfeeding and risk of EC is provided in Figure 2 and Figure 3.

\section{Subgroup analysis by continent}

We found a strong and significant association of breastfeeding with EC risk in Asia $(R R=0.57,95 \%$ $C I$ 0.37-0.87), but the association was not significant in Europe $(R R=1.00,95 \% C I 0.66-1.53)$ and in NorthAmerica $(R R=0.82,95 \%$ CI 0.60-1.13).

\section{Subgroup analysis by study design}

Inverse association was found for cohort studies. The pooled $R R$ for cohort studies was 0.62 (95\% CI 0.41-0.94; $\left.I^{2}=36.5 \% ; p>0.05\right)$, and the pooled $R R$ for case-control studies was $0.78\left(95 \%\right.$ CI $\left.0.59-1.04 ; I^{2}=67.9 \% ; p<0.05\right)$.

\section{Subgroup analysis by adjustment for covariates}

We found no significant association in stratified analysis by adjustment (yes or no) for the following covariates: postmenopausal hormone replacement therapy use, oral contraceptive use, body mass index (BMI), menarche age and menopausal status. Moderate or lower between-study heterogeneity was found in all analyses. Table 2 showed the results from all analyses.

\section{Dose-response analysis}

For dose-response analysis, eight studies including 2919 EC cases [19, 21-23, 25-27, 30] provided the data. We found a linear relationship of breastfeeding with EC ( $p$ for nonlinearity $=0.93$ ). Compared with 0 month, the $R R \mathrm{~s}(95 \% C I)$ of EC were 0.99 (0.99-1.00), $0.92(0.86-$ $0.98), 0.83(0.74-0.94)$ and $0.79(0.69-0.90)$ for $0.5,6,14$ and 18 months separately. The dose-response analysis suggested that EC risk decreased by $1.2 \%$ for one month increment of breastfeeding (Figure 4).

\section{Sources of heterogeneity and sensitive analysis}

Moderate between-study heterogeneity was found in this analysis. Exploratory univariate meta-regression was performed with the covariates of published year, study area, study type, cases and sample size. However, results showed that no covariate had a significant impact on between-study heterogeneity (published year: $p=0.354$, study region: $p=0.879$, study type: $p=0.441$, cases: $p=0.143$, sample size: $p=0.911$ ). The 'leave one-out' sensitive analysis [33] was carried out to assess the key studies contributed to this high between-study heterogeneity. After excluding three articles conducted by Rosenblatt KA et al [21], SalazarMartinez E [22] and Zucchetto A [29], no significant heterogeneity $\left(I^{2}=42.1 \%, p>0.05\right)$ was found, and the pooled $R R$ was $0.78(95 \% C I 0.64-0.96)$.

\section{Influence analysis}

No individual study was found to have excessive influence on the pooled effects for conclusion (specific data were not provided).

\section{Publication bias evaluation}

Publication bias was detected by Egger test and the visual inspection of the funnel plot. No significant asymmetry of the funnel plot was found in the Egger test $(p=0.097)$ (Figure 5).

\section{DISCUSSION}

To our knowledge, this is the first meta-analysis to examine the association between breastfeeding and EC. From the results we found that breastfeeding was associated with a statistically significant decreased risk of EC, and there was a notable linear relationship between duration of breastfeeding and risk of EC. Dose-response analysis revealed that EC risk decreased by $1.2 \%$ for 1 month increment of breastfeeding. The summary $R R \mathrm{~s}(95 \% \mathrm{CIs})$ of 

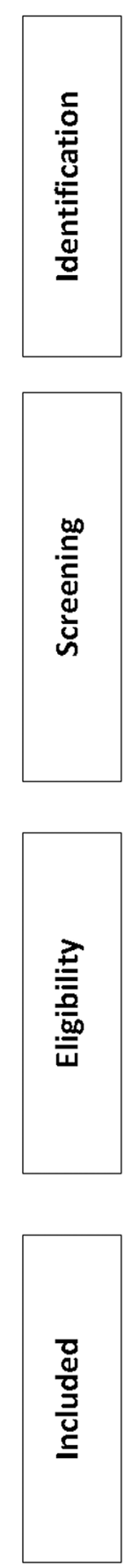

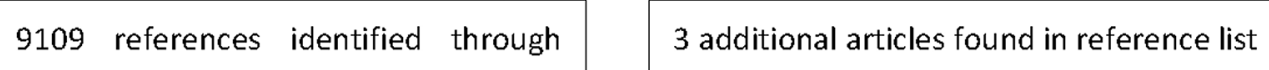

3 additional articles found in reference list

9000 articles excluded after review of title and abstract
Articles excluded because: 95 articles did not provide the result for breastfeeding, 2 articles did not provide RR and/or $95 \% \mathrm{Cl}$

15 articles included in this meta-analysis

\section{Figure 1: Flowchart of the selection of studies included in the meta-analysis.}

EC did not substantially change in the sensitivity analysis. Subgroup analysis by study design showed the inverse association between breastfeeding and EC for cohort studies. These results proved that our results were stable and credible.

We found a strong and significant association of breastfeeding with EC risk in Asia $(R R=0.57,95 \%$ CI 0.37-0.87). In Asia, Europe and North America, the traditional culture and people's lifestyles are different. First, more Asians tend to choose breastfeeding as the way to feed children with respect to the Europeans and North Americans, and the duration of breastfeeding is longer [31]. Second, genetic factors are various among different continents. Third, the BMI of Europeans and North Americans is higher than Asians, which has been associated with a higher risk of EC [34]. These may explain the different results of the three continents.

Several hypotheses have been provided to describe the association between breastfeeding and EC. In general, EC is related to female hormones [35-37]. When endometrium is continuously stimulated by estrogens, mitotic activity is promoted. The increasing possibility of genetic mutations results in a carcinoma eventually [38, 39]. During lactation, 
Table 1: Characteristics of studies included in the meta-analysis of breastfeeding and endometrial cancer

\begin{tabular}{|c|c|c|c|c|c|}
\hline Author(year) & Country & Study design, age & $\begin{array}{l}\text { Sample size } \\
\quad \text { (cases) }\end{array}$ & $\begin{array}{c}\text { RR }(95 \% \mathrm{CI}) \\
\text { for highest vs. } \\
\text { lowest category }\end{array}$ & $\begin{array}{l}\text { Adjustment for } \\
\text { covariates }\end{array}$ \\
\hline $\begin{array}{l}\text { Sugawara } \\
\text { et al.(2013) }\end{array}$ & Japan & cohort,40-79 & $19,848(32)$ & $0.31(0.12-0.81)$ & $\begin{array}{l}\text { Age, BMI, family } \\
\text { history of cancer, } \\
\text { education, job status, } \\
\text { smoking status, } \\
\text { alcohol consumption, } \\
\text { time spent walking, } \\
\text { total calorie intake, } \\
\text { menopausal status, age } \\
\text { at menarche, age at } \\
\text { first delivery, number } \\
\text { of deliveries, history of } \\
\text { oral contraceptive drug } \\
\text { use, history of hormone } \\
\text { replacement therapy }\end{array}$ \\
\hline $\begin{array}{l}\text { Dossus } \\
\text { et al.(2009) }\end{array}$ & $\begin{array}{l}\text { Denmark, } \\
\text { France, Germany, } \\
\text { Greece, Italy, } \\
\text { the Netherlands, } \\
\text { Norway, Spain, } \\
\text { Sweden and } \\
\text { United Kingdom }\end{array}$ & cohort,-- & $302,618(1017)$ & $0.77(0.54-1.11)$ & $\begin{array}{c}\text { Age, BMI, physical } \\
\text { activity, alcohol, } \\
\text { diabetes, smoking status, } \\
\text { education }\end{array}$ \\
\hline $\begin{array}{l}\text { Zucchetto } \\
\text { et al.(2009) }\end{array}$ & Italy & cc, $60 / 61$ & $1,362(454)$ & $1.33(0.95-1.85)$ & $\begin{array}{l}\text { Age, period of interview, } \\
\text { BMI, age at menarche, } \\
\text { age at menopause, } \\
\text { parity, oral contraceptive } \\
\text { use, when appropriate }\end{array}$ \\
\hline $\begin{array}{l}\text { Brinton } \\
\text { et al.(2007) }\end{array}$ & Polish & cc, $20-74$ & $2,476(551)$ & $0.72(0.4-1.2)$ & $\begin{array}{l}\text { Age, study site, years } \\
\text { of education, age at } \\
\text { menarche, number } \\
\text { of full-term births, } \\
\text { ever use of oral } \\
\text { contraceptives, ever use } \\
\text { of oral hormones, ever } \\
\text { smoking, BMI }\end{array}$ \\
\hline $\begin{array}{l}\text { Okamura } \\
\text { et al.(2006) }\end{array}$ & Japan & cc,51.6/49.6 & $251(155)$ & $0.37(0.17-0.82)$ & $\begin{array}{l}\text { Age, BMI, oral } \\
\text { contraceptive use }\end{array}$ \\
\hline $\begin{array}{l}\text { Wernli } \\
\text { et al.(2006) }\end{array}$ & China & cohort,-- & $259,640(206)$ & $0.62(0.35-1.09)$ & $\begin{array}{c}\text { Age at baseline, number } \\
\text { of live births }\end{array}$ \\
\hline $\begin{array}{l}\mathrm{Xu} \\
\text { et al.(2004) }\end{array}$ & China & cc,30-69 & $1,559(754)$ & $0.54(0.33-0.87)$ & $\begin{array}{c}\text { Age, BMI, family } \\
\text { history of cancer, } \\
\text { number of pregnancies, } \\
\text { history of abortion, } \\
\text { duration of menstruation }\end{array}$ \\
\hline $\begin{array}{l}\text { Herrinton } \\
\text { et al.(2001) }\end{array}$ & United States & cc, $20-54$ & $896(179)$ & $0.95(0.65-1.4)$ & \\
\hline
\end{tabular}

(Continued) 


\begin{tabular}{|c|c|c|c|c|c|}
\hline Author(year) & Country & Study design, age & $\begin{array}{l}\text { Sample size } \\
\text { (cases) }\end{array}$ & $\begin{array}{c}\text { RR }(95 \% \mathrm{CI}) \\
\text { for highest vs. } \\
\text { lowest category }\end{array}$ & $\begin{array}{l}\text { Adjustment for } \\
\text { covariates }\end{array}$ \\
\hline $\begin{array}{l}\text { Newcomb } \\
\text { et al.(2000) }\end{array}$ & United States & cc, $40-79$ & $2,239(586)$ & $0.84(0.52-1.4)$ & $\begin{array}{l}\text { Age, smoking status, } \\
\text { education, body mass, } \\
\text { postmenopausal } \\
\text { hormone therapy, parity }\end{array}$ \\
\hline $\begin{array}{l}\text { Salazar- } \\
\text { Martinez } \\
\text { et al.(1999) }\end{array}$ & Mexico & cc, $57.1 / 54.6$ & $837(85)$ & $0.33(0.17-0.65)$ & $\begin{array}{l}\text { Age, hormonal use, } \\
\text { number of pregnancies, } \\
\text { smoking, diabetes } \\
\text { mellitus, hypertension, } \\
\text { physical activity, } \\
\text { menopausal status, BMI }\end{array}$ \\
\hline $\begin{array}{l}\text { Hirose } \\
\text { et al.(1999) }\end{array}$ & Japan & cc, $48.5 / 56.6$ & $26,953(1465)$ & $1.48(0.63-3.49)$ & Age, BMI \\
\hline $\begin{array}{l}\text { Rosenblatt } \\
\text { et al.(1995) }\end{array}$ & $\begin{array}{l}\text { Australia Israel } \\
\text { Chile, China, } \\
\text { Philippines, and } \\
\text { Thailand }\end{array}$ & $\mathrm{cc},-$ & $1,069(136)$ & $0.23(0.08-0.68)$ & $\begin{array}{c}\text { Number of pregnancies, } \\
\text { age at menarche }\end{array}$ \\
\hline $\begin{array}{l}\text { Brinton } \\
\text { et al.(1992) }\end{array}$ & United States & $\mathrm{cc},-$ & $702(405)$ & $1.01(0.6-1.6)$ & $\begin{array}{l}\text { Age, number of births, } \\
\text { years of education, } \\
\text { recent weight, oral } \\
\text { contraceptive use, } \\
\text { menopausal estrogen use }\end{array}$ \\
\hline $\begin{array}{l}\text { Cusimano } \\
\text { et al. (1989) }\end{array}$ & Italy & cc, $61.7 / 60.2$ & $480(57)$ & $2.94(0.68-12.5)$ & Unclear \\
\hline $\begin{array}{l}\text { Elwood } \\
\text { et al.(1977) }\end{array}$ & United States & cc,55-59 & $2,640(622)$ & $1(0.7-1.5)$ & $\begin{array}{l}\text { Age, marital status, } \\
\text { parity, age at first birth, } \\
\text { age at menarche, age } \\
\text { at natural menopause, } \\
\text { history of stillbirth or } \\
\text { miscarriage }\end{array}$ \\
\hline
\end{tabular}

pituitary and ovarian hormones are suppressed [40, 41], reducing stimulation of the endometrium by estrogen [42]. Another hypothesis that has been raised to explain endometrial carcinogenesis is the "unopposed estrogen" hypothesis [43]. It asserts that a high level of estrogens stimulates cells proliferation of the endometrium, when they are not counterbalanced by progesterone [42]. During breastfeeding the decline of estrogen is more significant than that of progesterone [40], so estrogen is opposed by progesterone. Overall, breastfeeding may alter EC risk through the hormonal [44]. On the other hand, longer duration of breastfeeding could strongly decrease the risk of overweight [45], which could subsequently and substantially increase the risk of endometrial cancer [46].

Between-study heterogeneity is common in metaanalysis [47], and it is demanded to explore the potential sources of between-study heterogeneity. Our metaanalysis showed moderate between-study heterogeneity. The different characteristics of each study may result in heterogeneity. In our meta-analysis, the number of the studies in our analysis is limited. Besides, the adjustment factors are various among the studies. For example, Cusimano et al. [32] did not indicate the adjustment factors in his research. On the other hand, Rosenblatt et al. [21] used extreme category greater than 72 months as the highest category, while Hirose et al. [30] used extreme category more than 12 months as the highest category. We used meta-regression to explore the potentially important causes of the between-study heterogeneity. However, our meta-analysis did not find the covariates as the contributors to the between-study heterogeneity. After the 'leave one-out' sensitive analysis, no significant heterogeneity $\left(I^{2}=42.1 \%, p>0.05\right)$ was found. The studies that we excluded in the 'leave one-out' sensitive analysis contained a relatively small number of cases, and the adjustment factors in the study of Rosenblatt KA et al [21] was less than others. Furthermore, the pooled $R R$ was 0.78 (95\% $C I$ 0.64-0.96) after the 'leave one-out' analysis. 


\begin{tabular}{|c|c|c|}
\hline author & year & $\mathrm{RR}(95 \% \mathrm{Cl})$ \\
\hline Sugawara & 2013 & $0.31(0.12,0.81)$ \\
\hline Dossus & 2010 & $0.77(0.54,1.11)$ \\
\hline Zucchetto & 2009 & $1.33(0.95,1.85)$ \\
\hline Brinton & 2007 & $0.72(0.40,1.20)$ \\
\hline Okamura & 2006 & $0.37(0.17,0.82)$ \\
\hline Wernli & 2006 & $0.62(0.35,1.09)$ \\
\hline $\mathrm{Xu}$ & 2004 & $0.54(0.33,0.87)$ \\
\hline Herrinton & 2001 & $0.95(0.65,1.40)$ \\
\hline Newcomb & 2000 & $0.84(0.52,1.40)$ \\
\hline Salazar-Martinez & 1999 & $0.33(0.17,0.65)$ \\
\hline Hirose & 1999 & $1.48(0.63,3.49)$ \\
\hline Rosenblatt & 1995 & $0.23(0.08,0.68)$ \\
\hline Brinton & 1992 & $1.01(0.60,1.60)$ \\
\hline Elwood & 1977 & $1.00(0.70,1.50)$ \\
\hline Cusimano & 1989 & $2.94(0.68,12.50)$ \\
\hline \multicolumn{2}{|c|}{ Overall (I-squared $=64.9 \%, p=0.000)$} & $0.74(0.58,0.95)$ \\
\hline \multicolumn{3}{|c|}{ NOTE: Weights are from random effects analysis } \\
\hline & .08 & \\
\hline
\end{tabular}

Figure 2: Forest plot for the pooled relative risk of breastfeeding for EC.

A major strength of this meta-analysis is the large number of included participants, allowing us to get the stable results. Second, most included studies had adjusted for potential confounders, increasing the credibility of the results. Third, dose-response analysis was performed to better describe the association of breastfeeding time with EC risk. In addition, the subgroup analysis by study design strongly identified the effect of breastfeeding on EC, the pooled $R R$ of cohort studies was $0.62(95 \% C I$ $0.41-0.94)$.

However, the limitations of our study should also be considered. First, further adjustments need to be conducted to clarify the independent role of breastfeeding to EC. Second, the adjustment factors of each study were different. Third, majority studies of this analysis were case-control design. Considering the recall bias of casecontrol studies, the effect of breastfeeding on EC requires confirmation in large cohort studies.

In summary, this meta-analysis confirms an inverse association between breastfeeding and EC risk especially in Asia. Our findings also confirm that longer time of breastfeeding may reduce the risk of EC. The association of breastfeeding and EC deserves further investigation.

\section{MATERIALS AND METHODS}

\section{Literature search strategy}

The initially relevant studies from PubMed, Web of Science, Chinese National Knowledge Infrastructure, China biology medical literature database, Wan fang databases and Database of Chinese Scientific and Technical Periodicals were identified up to 11 July 2015. All the articles were restricted to English or Chinese language. The following strategy was used in this search: $((()(($ reproductive) $)$ OR reproduction))) OR ((breastfeeding) OR lactation))) AND ((endometrial cancer OR endometrial neoplasm OR endometrial carcinoma OR uterine corpus)). In addition, the reference lists from retrieved articles were also reviewed to identify relevant studies $[34,46]$.

\section{Inclusion criteria}

All studies were reviewed independently by the first and the second authors. If the two authors disagreed about the eligibility of an article, it was resolved by consensus with the third author. The studies must meet 


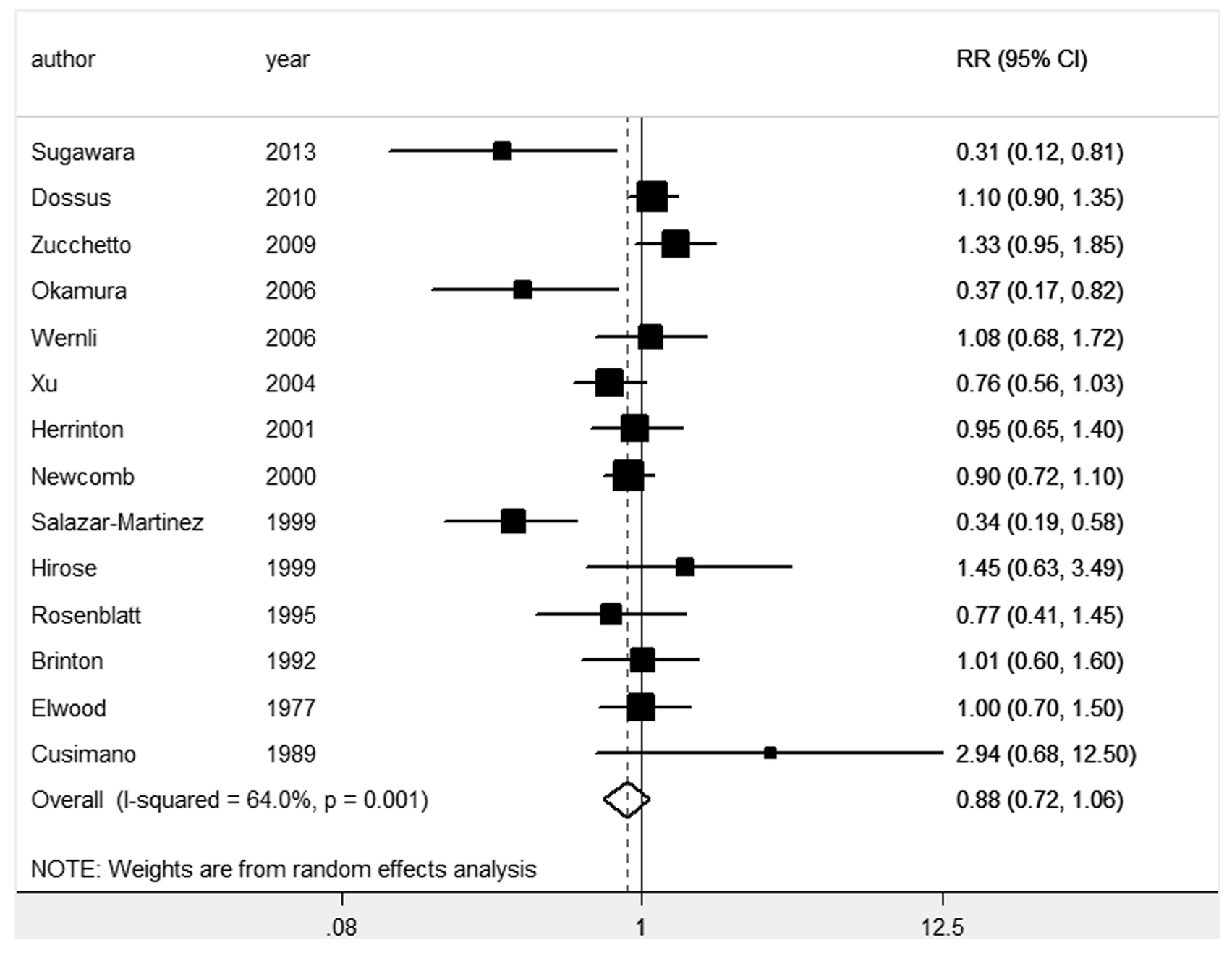

Figure 3: Forest plot for the pooled relative risk of breastfeeding for EC (the ever breastfeeding compared with the reference group).

the following inclusion criteria: (1) case-control or cohort studies published as original studies to evaluate the association between breastfeeding and risk of EC incidence. (2) Odds ratio (OR), relative risk $(R R)$ or hazard ratio with $95 \%$ confidence interval $(C I)$ were available. (3) The number of cases and participants or person-years for different duration of breastfeeding must be provided in order to do the dose-response analysis. If multiple articles were published from the same study, we choose the complete one or the study which can provide sufficient detail of data.

\section{Data extraction}

The following items were extracted from each study: the first author's name, sample size, EC cases, study type, publication year, continent, follow-up years for cohort studies, adjustment for potential confounding, $R R$ s and $95 \% C I s$ (we presented all results with $R R$ for simplicity). We extracted $R R \mathrm{~s}$ adjusted with the most confounders. For dose-response analysis, the number of cases, participants (person-years), and $R R(95 \% C I)$ for each category of breastfeeding were extracted, as well as the different duration of breastfeeding [48]. The study quality was assessed using the Newcastle-Ottawa quality assessment scale.

\section{Statistical analysis}

Pooled measure was calculated as the inverse variance-weighted method of the logarithm of $R R$ with $95 \%$ CI by the inverse variance-weighted method. We used the Q test and the $I^{2}$ statistic to assess the heterogeneity among studies [49]. The REM was applied as the pooling method [50].

Meta regression and subgroup analyses were conducted to explore the possible sources of betweenstudy heterogeneity. The restricted maximum likelihood method (REML) was used to estimate the additive (between-study) component of variance tau^ 2 in metaregression. The 'leave one-out' sensitive analysis [33] was carried out to evaluate the key studies. Influence analysis was performed to validate the stability of outcomes by removing one study at a time. Publication 
Table 2: Pooled measures on the relation of breastfeeding and EC

\begin{tabular}{|c|c|c|c|c|c|}
\hline \multirow[b]{2}{*}{ Subgroup } & \multirow[b]{2}{*}{$\begin{array}{c}\text { Number of } \\
\text { studies }\end{array}$} & \multicolumn{4}{|c|}{ Heterogeneity } \\
\hline & & RR (95\%CI) & $I^{2}(\%)$ & $P$ value & Article included \\
\hline All & 15 & $0.74(0.58$ to 0.95$)$ & 64.9 & 0.00 & $18-32$ \\
\hline Ever/never & 14 & $0.88(0.72$ to 1.06$)$ & 64.0 & 0.00 & $18-31$ \\
\hline \multicolumn{6}{|l|}{ Study region } \\
\hline Asia & 5 & $\begin{array}{c}0.57(0.37 \text { to } \\
0.87)\end{array}$ & 47.6 & 0.11 & $23,27,28,30,31$ \\
\hline Europe & 4 & $\begin{array}{c}1.00(0.66 \text { to } \\
1.53)\end{array}$ & 63.9 & 0.04 & $19,26,29,32$ \\
\hline North America & 5 & $\begin{array}{c}0.82(0.60 \text { to } \\
1.13)\end{array}$ & 56.1 & 0.06 & $18,20,22,24,25$ \\
\hline Other & 1 & $\begin{array}{c}0.23(0.08 \text { to } \\
0.66)\end{array}$ & - & - & 21 \\
\hline \multicolumn{6}{|l|}{ Study design } \\
\hline Cohort study & 3 & $0.62(0.41$ to 0.94$)$ & 36.5 & 0.21 & $19,27,28$ \\
\hline Case-control study & 12 & $0.78(0.59$ to 1.04$)$ & 67.9 & 0.00 & $18,20-26,29-32$ \\
\hline \multicolumn{6}{|l|}{$\begin{array}{l}\text { Adjustment for } \\
\text { hormone use }\end{array}$} \\
\hline Yes & 5 & $0.63(0.41$ to 0.97$)$ & 61.1 & 0.04 & $18,22,25,26,28$ \\
\hline No & 9 & $0.77(0.58$ to 1.03$)$ & 67.4 & 0.00 & $\begin{array}{c}19-21,23 \\
24,27,29-31\end{array}$ \\
\hline \multicolumn{6}{|l|}{$\begin{array}{l}\text { Adjustment for oral } \\
\text { contraceptive use }\end{array}$} \\
\hline Yes & 5 & $0.72(0.44$ to 1.19$)$ & 74.6 & 0.00 & $18,26,28,29,31$ \\
\hline No & 9 & $0.71(0.54$ to 0.93$)$ & 58.0 & 0.02 & $19-25,27,30$ \\
\hline \multicolumn{6}{|l|}{$\begin{array}{l}\text { Adjustment for body } \\
\text { mass index }\end{array}$} \\
\hline Yes & 8 & $0.65(0.44$ to 0.96$)$ & 74.7 & 0.00 & $\begin{array}{l}19,22,23 \\
26,28-31\end{array}$ \\
\hline No & 7 & $0.83(0.63$ to 1.08$)$ & 41.4 & 0.13 & $\begin{array}{l}18,20,21 \\
24,25,27\end{array}$ \\
\hline \multicolumn{6}{|l|}{$\begin{array}{l}\text { Adjustment for } \\
\text { menarche age }\end{array}$} \\
\hline Yes & 5 & $0.70(0.42$ to 1.17$)$ & 76.7 & 0.00 & $20,21,26,28,29$ \\
\hline No & 9 & $0.71(0.55$ to 0.92$)$ & 51.6 & 0.04 & $\begin{array}{c}18,19,22- \\
25,27,30,31\end{array}$ \\
\hline \multicolumn{6}{|l|}{$\begin{array}{l}\text { Adjustment for } \\
\text { menopausal status }\end{array}$} \\
\hline Yes & 5 & $0.65(0.38$ to 1.11$)$ & 82.6 & 0.00 & $20,22,23,28,29$ \\
\hline No & 9 & $0.76(0.60$ to 0.97$)$ & 41.2 & 0.09 & $\begin{array}{c}18,19,21, \\
24-27,30,31\end{array}$ \\
\hline
\end{tabular}




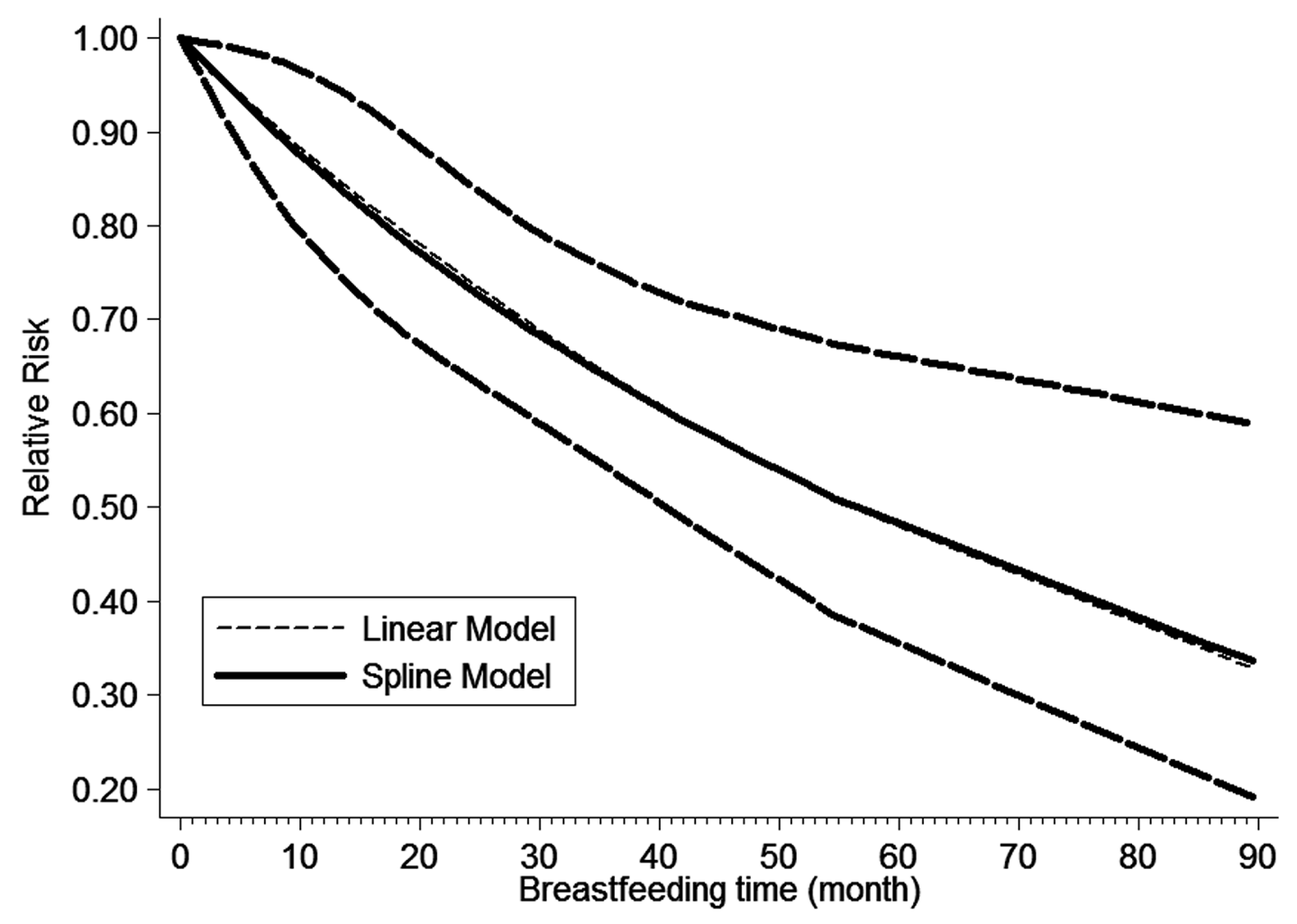

Figure 4: The dose-response analysis between breastfeeding and EC risk with restricted cubic splines in a multivariate random-effects dose-response model. The solid line and the long dash line represent the estimated relative risk and its $95 \%$ confidence interval. Short dash line represents the linear relationship

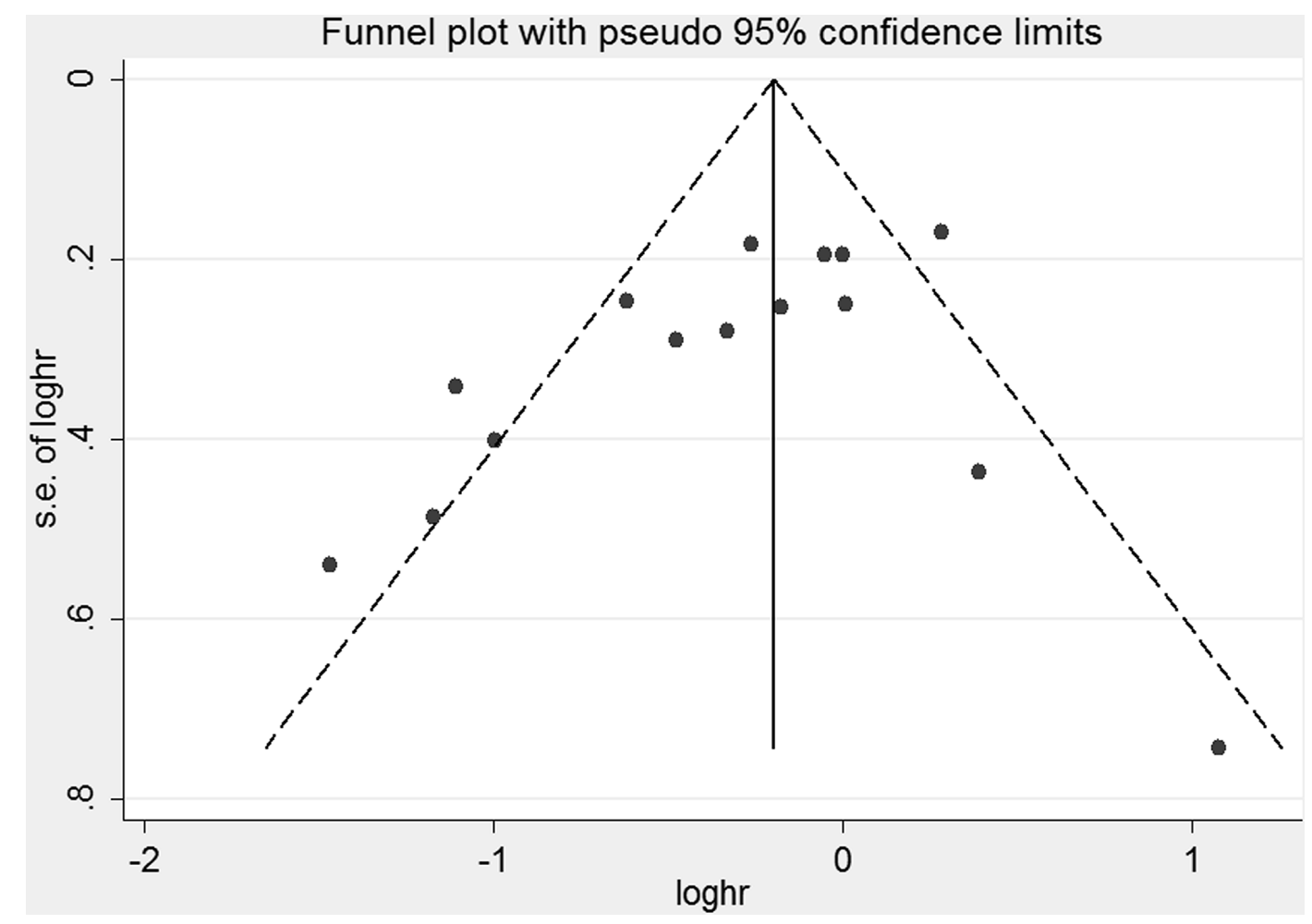

Figure 5: Funnel plot for the analysis of breastfeeding and EC risk after removing three studies that had a strong effect on heterogeneity. 
bias was assessed by visual inspection of the funnel plot and Egger's test [51].

For the does-response analysis, the method described by Orsini et al [52] was used. A two-stage random-effects dose-response meta-analysis was performed to compute the trend from the correlated $\log R R$ estimates across duration of breastfeeding. First, we created a restricted cubic spline model with three knots at the 10 th, 50 th, and 90 th centiles. Then the REML method was used to combine the study-specific estimates in a multivariate random-effects meta-analysis [53]. By testing the null hypothesis that the coefficient of the second spline is equal to $0, p$ value for nonlinearity was calculated. All statistical analyses were conducted by Stata V.12.0 (Stata Corp, College Station, Texas, USA). A 2-sided and a $p<0.05$ was considered statistically significant.

\section{ACKNOWLEDGMENTS}

None declared.

\section{FUNDING}

None declared

\section{CONFLICTS OF INTEREST}

The authors declare that there are no conflicts of interest.

\section{REFERENCES}

1. Ferlay J, Soerjomataram I, Dikshit R, Eser S, Mathers C, Rebelo M, Parkin DM, Forman D, Bray F. Cancer incidence and mortality worldwide: sources, methods and major patterns in GLOBOCAN 2012. Int J Cancer. 2015; 136:359-386.

2. Torre LA, Bray F, Siegel RL, Ferlay J, Lortet-Tieulent J, Jemal A. Global cancer statistics, 2012. CA Cancer J Clin. 2015; 65:87-108

3. DeSantis CE, Lin CC, Mariotto AB, Siegel RL, Stein KD, Kramer JL, Alteri R, Robbins AS, Jemal A. Cancer treatment and survivorship statistics, 2014. CA Cancer J Clin. 2014; 64:252-271.

4. Siegel R, Ma J, Zou Z, Jemal A. Cancer statistics, 2014. CA Cancer J Clin. 2014; 64:9-29.

5. McCullough ML, Bandera EV, Patel R, Patel AV, Gansler T, Kushi LH, Thun MJ, Calle EE. A prospective study of fruits, vegetables, and risk of endometrial cancer. Am J Epidemiol. 2007; 166:902-911.

6. Pabalan N, Pineda MR, Jarjanazi H, Christofolini DM, Barbosa CP, Bianco B. Association of the $+331 \mathrm{G} / \mathrm{A}$ progesterone receptor gene $(\mathrm{PgR})$ polymorphism with risk of endometrial cancer in Caucasian women: a meta-analysis. Arch Gynecol Obstet. 2015; 291:115-122.
7. Aune D, Navarro Rosenblatt DA, Chan DS, Vingeliene S, Abar L, Vieira AR, Greenwood DC, Bandera EV, Norat T. Anthropometric factors and endometrial cancer risk: a systematic review and dose-response meta-analysis of prospective studies. Ann Oncol. 2015; 26:1635-1648.

8. Buchanan EM, Weinstein LC, Hillson C. Endometrial cancer. Am Fam Physician. 2009; 80:1075-1080.

9. Cote ML, Alhajj T, Ruterbusch JJ, Bernstein L, Brinton LA, Blot WJ, Chen C, Gass M, Gaussoin S, Henderson B, Lee E, Horn-Ross PL, Kolonel LN, Kaunitz A, Liang X, Nicholson WK, et al. Risk factors for endometrial cancer in black and white women: a pooled analysis from the Epidemiology of Endometrial Cancer Consortium (E2C2). Cancer Causes Control. 2015; 26:287-296.

10. Reis N, Beji NK. Risk factors for endometrial cancer in Turkish women: results from a hospital-based case-control study. Eur J Oncol Nurs. 2009; 13:122-127.

11. Ali AT. Reproductive factors and the risk of endometrial cancer. Int J Gynecol Cancer. 2014; 24:384-393.

12. Gartner LM, Morton J, Lawrence RA, Naylor AJ, O'Hare D, Schanler RJ, Eidelman AI. Breastfeeding and the use of human milk. Pediatrics. 2005; 115:496-506.

13. Labbok MH. Effects of breastfeeding on the mother. Pediatr Clin North Am. 2001; 48:143-158.

14. Martin RM, Middleton N, Gunnell D, Owen CG, Smith GD. Breast-feeding and cancer: the Boyd Orr cohort and a systematic review with meta-analysis. J Natl Cancer Inst. 2005; 97:1446-1457.

15. Li DP, Du C, Zhang ZM, Li GX, Yu ZF, Wang X, Li PF, Cheng C, Liu YP, Zhao YS. Breastfeeding and ovarian cancer risk: a systematic review and meta-analysis of 40 epidemiological studies. Asian Pac J Cancer Prev. 2014; 15:4829-4837.

16. Zhou Y, Chen J, Li Q, Huang W, Lan H, Jiang H. Association Between Breastfeeding and Breast Cancer Risk: Evidence from a Meta-analysis. Breastfeed Med. 2015; 10:175-182.

17. Amitay EL, Keinan-Boker L. Breastfeeding and Childhood Leukemia Incidence: A Meta-analysis and Systematic Review. JAMA Pediatr. 2015; 169:e151025.

18. Brinton LA, Berman ML, Mortel R, Twiggs LB, Barrett RJ, Wilbanks GD, Lannom L, Hoover RN. Reproductive, menstrual, and medical risk factors for endometrial cancer: results from a case-control study. Am J Obstet Gynecol. 1992; 167:1317-1325.

19. Dossus L, Allen N, Kaaks R, Bakken K, Lund E, Tjonneland A, Olsen A, Overvad K, Clavel-Chapelon F, Fournier A, Chabbert-Buffet N, Boeing H, Schutze M, Trichopoulou A, Trichopoulos D, Lagiou P, et al. Reproductive risk factors and endometrial cancer: the European Prospective Investigation into Cancer and Nutrition. Int J Cancer. 2010; $127: 442-451$.

20. Elwood JM, Cole P, Rothman KJ, Kaplan SD. Epidemiology of endometrial cancer. J Natl Cancer Inst. 1977; 59:1055-1060. 
21. Rosenblatt KA, Thomas DB. Prolonged lactation and endometrial cancer. WHO Collaborative Study of Neoplasia and Steroid Contraceptives. Int J Epidemiol. 1995; 24:499-503.

22. Salazar-Martinez E, Lazcano-Ponce EC, Gonzalez Lira-Lira G, Escudero-De los Rios P, Salmeron-Castro J, Hernez-Avila M. Reproductive factors of ovarian and endometrial cancer risk in a high fertility population in Mexico. Cancer Res. 1999; 59:3658-3662.

23. Wanghong X, Yongbing X, Fan J. Lactation and the risk of endometrial cancer-a population-based casecontrol study in shanghai women. Tumer. 2004; 24:417-421.

24. Herrinton LJ, Voigt LF, Weiss NS, Beresford SA, PA W. Risk factors for synchronous primary endometrial and ovarian cancers. Ann Epidemiol. 2001; 11:529-533.

25. Brinton LA, Sakoda LC, Lissowska J, Sherman ME, Chatterjee N, Peplonska B, Szeszenia-Dabrowska N, Zatonski W, Garcia-Closas M. Reproductive risk factors for endometrial cancer among Polish women. Br J Cancer. 2007; 96:1450-1456.

26. Newcomb PA, Trentham-Dietz A. Breast feeding practices in relation to endometrial cancer risk, USA. Cancer Causes Control. 2000; 11:663-667.

27. Wernli KJ, Ray RM, Gao DL, De Roos AJ, Checkoway H, Thomas DB. Menstrual and reproductive factors in relation to risk of endometrial cancer in Chinese women. Cancer Causes Control. 2006; 17:949-955.

28. Sugawara Y, Kakizaki M, Nagai M, Tomata Y, Hoshi R, Watanabe I, Nishino Y, Kuriyama S, Tsuji I. Lactation pattern and the risk for hormone-related female cancer in Japan: the Ohsaki Cohort Study. Eur J Cancer Prev. 2013; 22:187-192.

29. Zucchetto A, Serraino D, Polesel J, Negri E, De Paoli A, Dal Maso L, Montella M, La Vecchia C, Franceschi S, Talamini R. Hormone-related factors and gynecological conditions in relation to endometrial cancer risk. Eur $\mathrm{J}$ Cancer Prev. 2009; 18:316-321.

30. Hirose K, Tajima K, Hamajima N, Kuroishi T, Kuzuya K, Miura S, Tokudome S. Comparative case-referent study of risk factors among hormone-related female cancers in Japan. Jpn J Cancer Res. 1999; 90:255-261.

31. Okamura C, Tsubono Y, Ito K, Niikura H, Takano T, Nagase S, Yoshinaga K, Terada Y, Murakami T, Sato S, Aoki D, Jobo T, Okamura K, Yaegashi N. Lactation and risk of endometrial cancer in Japan: a case-control study. Tohoku J Exp Med. 2006; 208:109-115.

32. Cusimano R, Dardanoni G, Dardanoni L, La Rosa M, Pavone G, Tumino R, Gafa L. Risk factors of female cancers in Ragusa population (Sicily) - 1. Endometrium and cervix uteri cancers. Eur J Epidemiol. 1989; 5:363-371.

33. Patsopoulos NA, Evangelou E, Ioannidis JP. Sensitivity of between-study heterogeneity in meta-analysis: proposed metrics and empirical evaluation. Int J Epidemiol. 2008; $37: 1148-1157$.

34. Zhang Y, Liu H, Yang S, Zhang J, Qian L, Chen X. Overweight, obesity and endometrial cancer risk: results from a systematic review and meta-analysis. Int $\mathrm{J}$ Biol Markers. 2014; 29: 21-29.

35. Rubin GL, Peterson HB, Lee NC, Maes EF, Wingo PA, Becker S. Estrogen replacement therapy and the risk of endometrial cancer: remaining controversies. Am J Obstet Gynecol. 1990; 162:148-154.

36. Shapiro S, Kaufman DW, Slone D, Rosenberg L, Miettinen OS, Stolley PD, Rosenshein NB, Watring WG, Leavitt T Jr, Knapp RC. Recent and past use of conjugated estrogens in relation to adenocarcinoma of the endometrium. N Engl J Med. 1980; 303:485-489.

37. Key TJ, MC P. The dose-effect relationship between 'unopposed' oestrogens and endometrial mitotic rate: its central role in explaining and predicting endometrial cancer risk. Br J Cancer. 1988; 57:205-212.

38. Akhmedkhanov A, Zeleniuch-Jacquotte A, Toniolo P. Role of exogenous and endogenous hormones in endometrial cancer: review of the evidence and research perspectives. Ann N Y Acad Sci. 2001; 943:296-315.

39. Henderson BE, Feigelson HS. Hormonal carcinogenesis. Carcinogenesis. 2000; 21:427-433.

40. Baird DT, McNeilly AS, Sawers RS, Sharpe RM. Failure of estrogen-induced discharge of luteinizing hormone in lactating women. J Clin Endocrinol Metab. 1979; 49:500-506.

41. Petrakis NL, Wrensch MR, Ernster VL, Miike R, Murai J, Simberg N, Siiteri PK. Influence of pregnancy and lactation on serum and breast fluid estrogen levels: implications for breast cancer risk. Int J Cancer. 1987; 40:587-591.

42. Key TJ, Pike MC. The dose-effect relationship between 'unopposed' oestrogens and endometrial mitotic rate: its central role in explaining and predicting endometrial cancer risk. Br J Cancer. 1988; 57:205-212.

43. Hoskins WJ, Perez CA, Young RC, Barakat RR, Markman M, Randall ME. Corpus: epithelial tumors. Gynecologic oncology. Principles and Practice of Gynecologic Oncology. (Philadelphia: Lippincott Williams \& Wilkins). (2005) 823-872

44. World Cancer Research Fund/American Institute for Cancer Research. Food, nutrition, physical activity, and the prevention of cancer: a global perspective. (Washington, DC: American Institute for Cancer Research) (2007)

45. Harder T, Bergmann R, Kallischnigg G, Plagemann A. Duration of breastfeeding and risk of overweight: a metaanalysis. Am J Epidemiol. 2005; 162:397-403.

46. Crosbie EJ, Zwahlen M, Kitchener HC, Egger M, Renehan AG. Body mass index, hormone replacement therapy, and endometrial cancer risk: a meta-analysis. Cancer Epidemiol Biomarkers Prev. 2010; 19:3119-3130.

47. Munafo MR, Flint J. Meta-analysis of genetic association studies. Trends Genet. 2004; 20:439-444.

48. Keum N, Ju W, Lee DH, Ding EL, Hsieh CC, Goodman JE, Giovannucci EL. Leisure-time physical activity and endometrial cancer risk: dose-response meta-analysis of epidemiological studies. Int J Cancer. 2014; 135:682-694. 
49. Higgins JP, Thompson SG. Quantifying heterogeneity in a meta-analysis. Stat Med. 2002; 21:1539-1558.

50. DerSimonian R, Laird N. Meta-analysis in clinical trials. Control Clin Trials. 1986; 7:177-188.

51. Egger M, Davey Smith G, Schneider M, Minder C. Bias in meta-analysis detected by a simple, graphical test. BMJ. 1997; 315:629-634.
52. Orsini N, Li R, Wolk A, Khudyakov P, Spiegelman D. Meta-analysis for linear and nonlinear dose-response relations: examples, an evaluation of approximations, and software. Am J Epidemiol. 2012; 175:66-73.

53. Jackson D, White IR, Thompson SG. Extending DerSimonian and Laird's methodology to perform multivariate random effects meta-analyses. Stat Med. 2010; 29:1282-1297. 